\title{
The Influence of Military Surgeons in the Development of Vascular Surgery
}

\author{
Lt Col B A Price \\ MD,MS,FRCS(Ed),FRCS,RAMC \\ Consultant Vascular Surgeon
}

Ministry of Defence Hospital Unit, Frimley Park, Camberley, Surrey GU16 5UJ.

SUMMARY: Surgical attention to major blood vessels has been necessary for as long as man has been involved in armed combat. A brief resume of the history of vascular surgery is outlined with special reference to the contribution made by the military surgeon in battle. The role of modern specialist techniques in vascular injuries in present day operations will be briefly discussed.

\section{Introduction}

Increasing technology, public opinion and political will, have forced the main subspecialites of general surgery to assert themselves and move on from being merely interests to dedicated fields of work. It is perceived that Vascular Surgery is relatively young given that many of the major innovations have taken place in the latter part of this century. Examples include the advent of thromboendarterectomy by $\mathrm{J}$ Cid dos Santos (1), the embolectomy balloon of Thomas Fogarty (2) and the earlier but nevertheless monumental contribution made by J Cid dos Santos' father Reynaldo who first reported aortography in 1929 (3), thirty-four years after Röentgen's discovery of X-rays (4). However it can be argued that Vascular Surgery has existed far longer since there has been the necessity to deal with major haemorrhage for as long as man has chosen to engage in conflict. Throughout history, the evolution of man is littered with violence and it is no surprise that trauma to major vascular structures was commonplace. The ancient soldier was well versed in the places to plunge sharp weapons to render his opponent rapidly sanguine. The earliest description of the ligature using hemp fibres for bleeding is from the "Samhita" by Sushruta, an Indian physician who lived some time between 800 and 600 BC (5). The Samhita is indeed considered to be the first medical textbook every written. This work was divided into six parts covering every aspect of medicine but surgery is to the fore. Sushruta described four ways of arresting haemorrhage following phlebotomy which he also practised namely; "Sandhana" which involved the application of astringents made from tree bark, "Skandana", staunching of bleeding by vasoconstriction using extreme cold, "Pachana" drying of the wound with hot ashes and finally, cautery to cause shrinkage "Dahana". It is remarkable that the ligature was not widely adopted until Ambroise Paré championed its use during the Italian campaigns in the sixteenth century (6). Sporadic descriptions appear in the literature much earlier than this but reliance seems to have been placed on more draconian methods. Celsus in the first century AD used linen pledgets soaked in cold water to arrest haemorrhage, which if this failed was replaced by wads soaked in vinegar. As a last resort the cautery was used. Rufus of Ephesus in the second century did use ligatures but also described the application of styptics, cautery and twisting of vessels to occlude them. Hippocrates in the fourth century BC was so fearful of the massive haemorrhage that could occur from excision of a gangrenous limb, that he advocated that the cleavage should take place across devitalised tissue. This was in order to prevent bleeding but that if it did occur cold should be applied to the healthy tissue and not to the gangrenous part. The first clear recognition of the difference between arteries and veins was from Galen in Ancient Rome. He devised methods for dealing with both. He was surgeon to the gladiators for three years and describes the use of styptics, cautery and the ligature. Aetius, a Byzantine physician of the sixth century wrote sixteen books on medicine in which he describes the proximal ligation of brachial aneurysms and varicose veins. Roger of Palermo provides a clear description of suture ligation or "mediate" suture in the eleventh century. In the third century the Christian Saints of surgery Cosmos and Damian were said to have performed the first transplant. Legend has it that an elderly servant of the church was afflicted with a cancer of one of his legs. Following lengthy prayer he fell asleep and dreamed that Cosmos and Damian came to his bedside and proceeded to remove the diseased leg. Remembering that a Moor slave had died earlier that day they hurried to the grave and exhumed the deceased's body. The appropriate leg was removed and used to replace that of the churchman. When the elder awoke he discovered that he had two legs; one black and one white. Astonished by this he hurried to the grave of the Moor to find an already enlarging and curious crowd surrounding the internment site. There was the Moor minus his leg with the churchman's diseased limb lying next to him. The twin brother saints became martyred in $287 \mathrm{AD}$ when they were put to death by the Governor of Lycia for refusing to accept idolatry $(5,7)$.

\section{Galen "The Clarissimus"}

Very little progress was made from these early times and it is remarkable that despite these isolated reports of the use of ligature, reliance on boiling oil or tar continued in combating haemorrhage particularly on the field of battle. Some historians blame the influence of Galen. The massive contribution made by Galen demonstrated by the huge quantity of books he wrote which numbered over 600 , is well recognised but it is clear that Galen was arrogant and unquestioning of his own beliefs once formed. He believed in the four humors namely blood, bile, black bile and phlegm and from these the answers to life the body and its workings lay. His comment "those who seek fame need only become familiar in everything I have achieved" revealed the level of the great ancient physician's conceit and his teachings became enshrined in religious folklore. This may go some way to explaining why medical advancement was held back for nearly fifteen centuries. However, it cannot be disputed that Galen was a fine exponent of the art of surgery at the time and was honoured with election to the post of physician to the gladiators on no less than four occasions. His record was a proud one; never failing to save the life of any gladiatorial combatant who was brought to $\operatorname{him}(5,7,8)$.

\section{The French Military Surgeons}

It was not until 1536 at the battle of Chateau de Villane, during the siege of Turin that Ambroise Paré was to change this philosophy. The change was forced upon him since as a young man himself of only 26 , he had followed the principles of the time in the use of boiling oil in the treatment of wounds. 


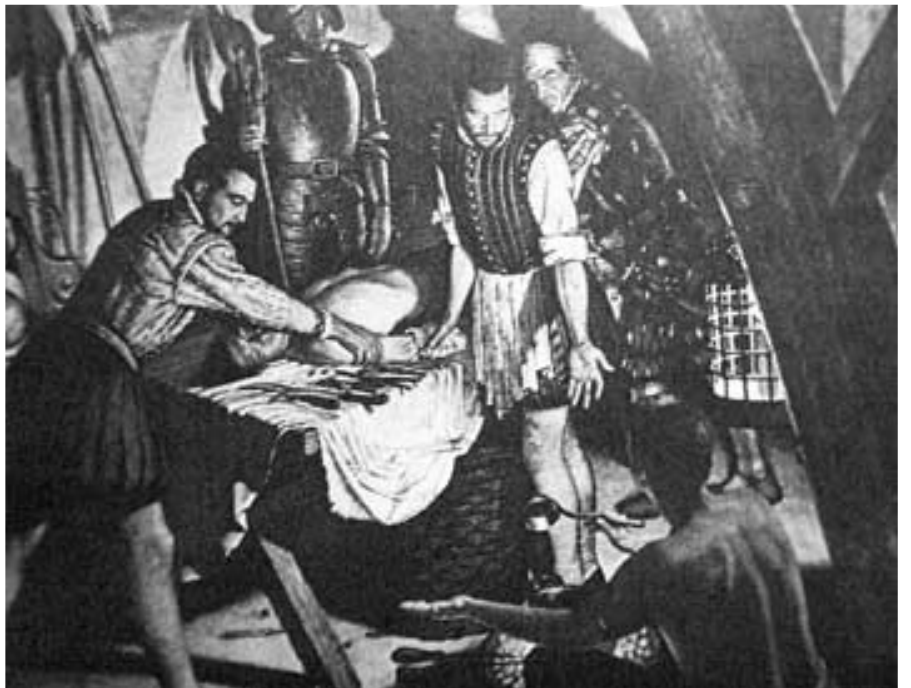

Fig 1. Paré's oil is exhausted.

Bacteriology was still undiscovered and therefore unbeknown to the practitioner's of the time, boiling oil not only stopped the bleeding but also sterilised the field. Physicians at this time believed that it was poisoning due to the gunpowder that caused what is now so clearly understood to be infection (6). Paré was aware that the price that had to be paid for this crude and barbaric treatment was excruciating pain and discomfort. He was only fortified by the support of his older and more experienced colleagues and therefore perpetuated the method. The change that was to be forced upon him came about because during a particularly fierce battle, the number of casualties was such that he ran out of oil and had to improvise (Fig 1). He mixed up a balm of egg yolk, turpentine and rose oil and applied this to the soldier's wounds, many of which were amputations. He had in effect a controlled trial since some of the casualties had already been treated along "conventional" lines. He slept badly that night worried that he had failed the men who had received the unorthodox treatment. He rose early to see them and to his astonishment he found the men who had received his simple dressing were sleeping and generally comfortable whilst those who had received the boiling oil were in agony, feverish with much swelling and inflammation around their wounds. Following this experience Paré resolved never to use hot oil or irons again and advocated the use of the ligatures for major vessels followed by simple dressings and bandages. Paré went further in modifying the use of an instrument used for bullet extraction as a vessel clamp to hold the occlude flow whilst the ligature was applied; the so called "Bec de Corbin" (5). Generations of surgeons have honed their skills tending the wounds of war and much advancement has sprung from necessity as in the example of Paré's ligature. His method would be the mainstay of treatment for vascular injuries until 1952. The French have a proud reputation as one of the foremost producers of military surgeons of whom Paré was but one. Petit developed a screw-mechanised tourniquet to facilitate amputation, which he used in 1718, and Ravaton reaffirmed Parés method of the use of ligatures fifty years following this. Another famous French military surgeon Dominique Jean Larrey (Fig 2), surgeon to Napoleon Bonapart was a skilled amputationist and used the ligature frequently. His most vital contribution of all to battlefield surgery however, was the ambulance volante or "flying ambulance" (Fig 3) which meant for the first time that wounded casualties were transported from the thick of the fighting to the rear where they could be cared for more thoroughly. It is ironic that the flying ambulance of today is just that with the advent of dedicated

\section{Fig 2. Dominique Jean Larrey}

helicopter transfer of casualties to medical help from the battlefields of Korea and Vietnam (5).

\section{Surgical Repair of Blood Vessels}

The helicopter has undoubtedly contributed to the scope of possibilities for vessel repair given faster transit but it is not, as generally accepted, the Korean conflict that saw the first attempts to repair major vascular injuries on the battlefield. Lieutenant-Colonel V Soubbotitch of the Serbian Army Reserve must claim that distinction in a report in the Lancet 1913 (9). In his results treating 60 arterial and 17 venous injuries 19 arteries and 13 veins were successfully treated by direct suture. This was a notable achievement since there had been a number of studies carried out in the preceding years that had not given cause for optimism. Ligation was still the preferred method of treating major vessel injuries and the work of Soubbotitch became forgotten for nearly four decades. The submergence of this work was not helped by a large series by Sir George Makins, Surgeon General to the British Armed Forces $(10,11)$. In over one thousand vascular injury cases reviewed from World War I, the vast majority were treated by ligation and he went on to unequivocally state that in the state of surgery at that time that ligation was the only option. He also

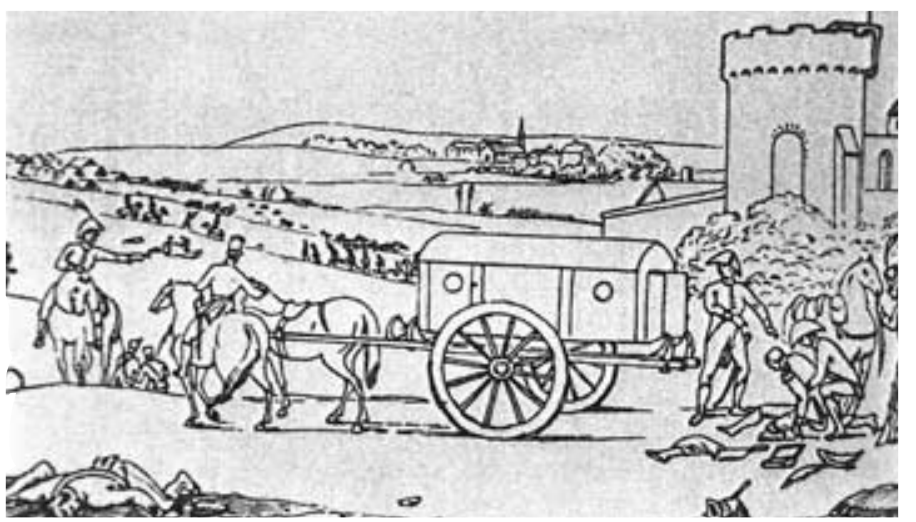

Fig 3. Larrey's "Ambulance volante" 
believed that ligation of the accompanying vein whether it was injured or not was beneficial on the grounds that it would keep blood that did enter the limb within the extremity for longer. Bernheim, treating American soldiers in the same conflict became disheartened by the disappointing results of attempts to repair blood vessels. He stated that it was foolhardy in the presence of such infections encountered on the battlefield (12). The German experience was equally discouraging. Jaeger actually attempted to use homografts from severed limbs to replace damaged vessels but these inevitably thrombosed and the practice was abandoned (13). Yet another military surgeon whose work was largely forgotten wrote extensively around this time. This was the Polish surgeon, Ramuald Weglowski. At the twenty-first Congress of the Polish Association of Surgery in 1924, he described 193 personal vascular operations including 46 cases of lateral suture repair, 12 end to end anastomoses and 56 venous grafts. He was one of the first to employ the inlay technique for the treatment of aneurysms, an innovation way ahead of it's time. Despite publishing 135 articles, 20 of which were in English, French and German, Weglowski's remarkable work is barely mentioned by others in the literature (14). The fact that attempts were being made to repair blood vessels in this pre-antibiotic era at all was remarkable given the great store set by modern day instrumentation and suture materials. Although the limitations of the time no doubt contributed to the poor results of the very early pioneers, sepsis was the major factor in the thrombosis that almost inevitably greeted vascular repair. Although Richard Lambert, a Newcastle surgeon had described the ingenious repair of a brachial artery by his close friend, Hallowell using a hat pin and a figure of eight suture on 15 June 1759 (15), successful repairs had been sporadic and resulted in universal failure otherwise. Further research was hampered until Lister's great discovery of antisepsis in 1867 (16). The first acknowledged series of vascular repair in animals was performed by Alexander Jassinowsky in 1889 (17) but Nikolai Eck's earlier, often forgotten work in the development of the portocaval fistula in dogs that still bears his name, showed clearly that it was technically possible to repair blood vessels (18). It is ironic that it was the requirement to go and do his military service in the Russian Army that forced Eck to abandon Pavlov's laboratory and his research. Repairing vessels was a remarkable achievement for the time but end to end anastomosis was to prove altogether more challenging and difficult. In 1900, Erwyn Payr devised a clever but ultimately unsuccessful method of joining vessels using magnesium rings $(19,20)$. Five years earlier, John Murphy of Chicago described an invagination technique for repairing a damaged femoral artery (21) later modified by the French surgeon Bouglé (22). Mathieu Jaboulay described the mattress suture technique to provide eversion, a principle used and recognised today (23). It was another French Surgeon however who was to make probably the greatest contribution to the suture of blood vessels and transplantation.

\section{Alexis Carrel}

Alexis Carrel was to serve in the French military on two occasions, once as a young man in 1895 and again during the First World War. It was between these times however that he was to make the groundbreaking contributions that were to win him the Nobel Prize for Medicine in 1912 (5). Carrel was inspired to work on the technical aspects of vascular suturing following the death of the French President, Sadi Carnot in 1894. Carnot was stabbed through the abdomen by an Italian anarchist, the blade severing his portal vein. Carnot died despite the attentions of the finest surgeons in France due to

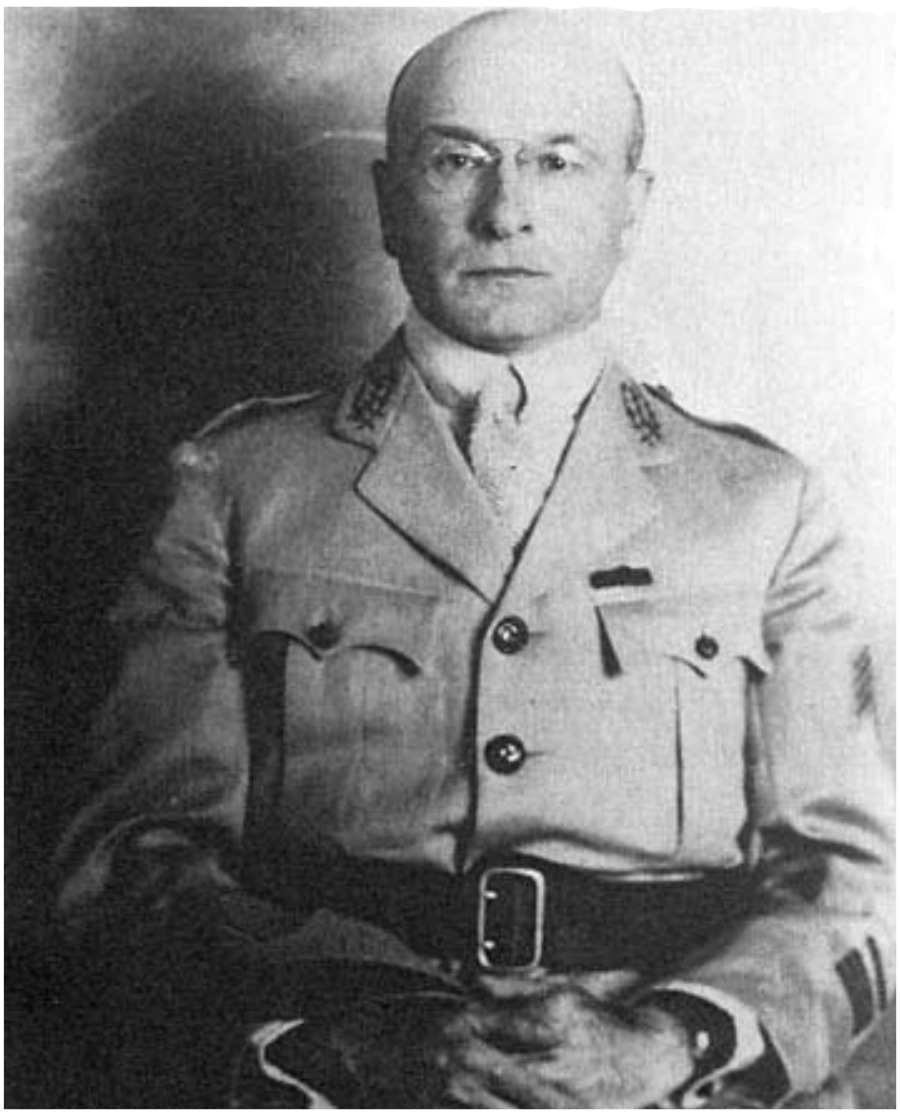

Fig 4. Alexis Carrel in the French Army

lack of expertise in vascular repair. Carrel set about the problem in Lyon in the laboratory of Mariel Soulier and developed fine sutures and needles. Despite his considerable intellect Carrel had problems passing a difficult faculty examination in surgery and finding his career path blocked in France left for Montreal in 1904. He moved to Chicago to continue his research later the same year. He was to form an alliance with a young physiologist called Charles Guthrie with whom he was to write 28 publications in 21 months, one of the most prolific outputs of all time. Their experimental work included the perfection of vascular suturing, the use of vein grafts and transplantation techniques and organ preservation. Their innovations were way ahead of their time given that the first routine venous bypass did not take place until 1948 (24), the first kidney transplant until 1955 (25) and the first reimplantation of a limb was not described until 1964 (26). Carrel described heart transplantation 62 years ahead of Christian Barnard's breakthrough in 1967 (27). In 1906 he moved on to the Rockefeller Institute of New York where his researches continued. In addition to describing mitral valvotomy $(28,29)$, ventricular aneurysmectomy and coronary artery bypass grafting (30) he became famous for his work on tissue culture (31). Carrel (Fig 4) was on holiday in France in 1914 when the First World War broke out and as a French citizen he was duty bound to serve his country. Treating the wounds of war rekindled his interest in wound healing. He tested hundreds of antiseptic solutions in collaboration with the chemist, Henry Dakin before coming up with the solution for irrigating wounds that still bears the latter's name (32). In 1917 Carrel commanded the first mobile army hospital, a forerunner to the Mobile Army Surgical Hospital (M.A.S.H.) units of the Korean and Vietnam campaigns that were to play so vital a role in the advancement of vascular surgery. After the Great War, Carrel returned to the Rockefeller Institute and worked with Charles Lindbergh on a perfusion pump for the preservation of organs (33). Their 
original research provided the foundation stones of the modern cardiac perfusion pumps today. In 1939 Carrel was forced into mandatory retirement at the age of 65 years and became somewhat embittered as a result. He nevertheless embraced a new challenge and poured his energies into setting up his own Institute in France. Carrel kept clear of all political matters and sought instead to promote his foundation. He met with the occupying Germans in order to protect the work of his Institute and as a result, he was accused of Nazi collaboration, the strain from which resulted in his first heart attack in 1943. Although he recovered and returned to his work, he had a further relapse a year later that left him severely restricted. Following the liberation of France the accusations of collaboration with the Nazis intensified although no proof was ever produced. He died on 5 November 1944 in the early hours of the morning. The final tragedy was that French Radio reported nine hours after his death that he had fled his home to avoid trial for collaboration. This unjust end to a life of devoted discovery does not nevertheless detract from his formidable achievements.

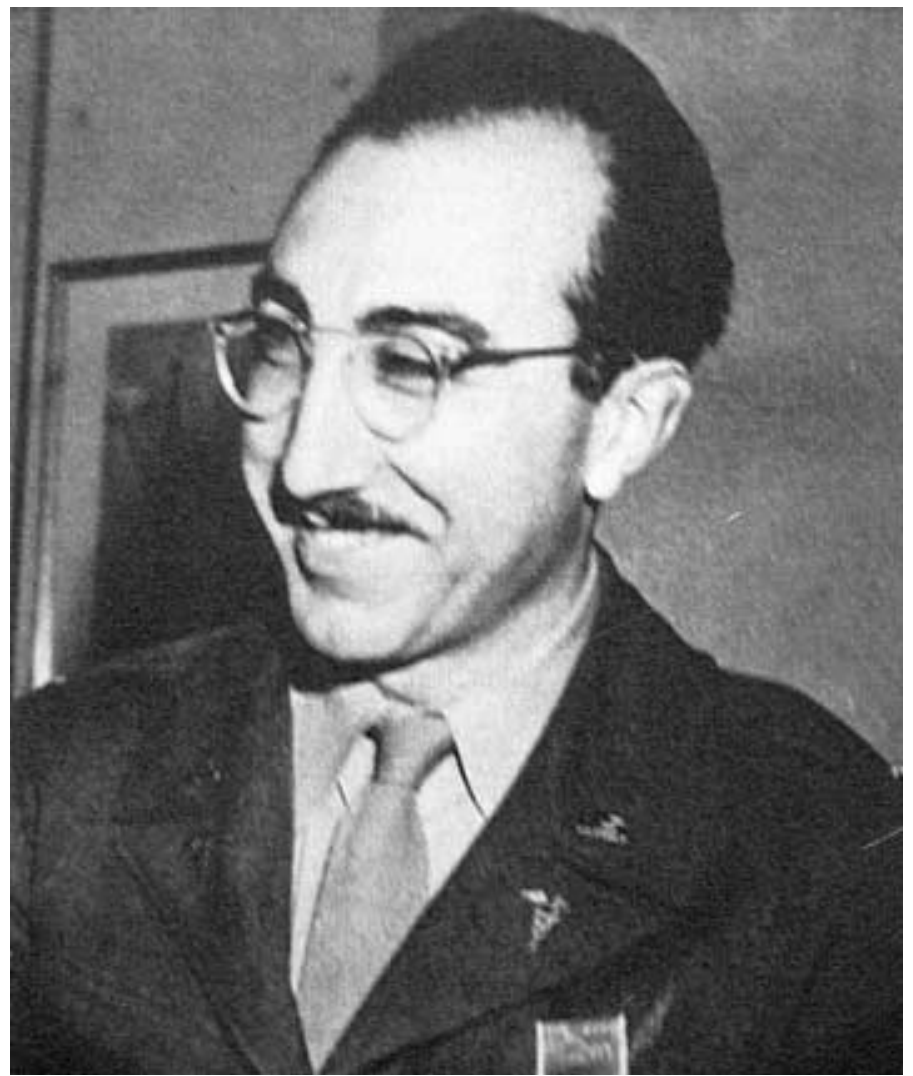

Fig 5. Mike DeBakey

\section{Advancement Since 1945}

DeBakey (Fig 5) and Simeone reported on 2,741 arterial wounds inflicted during the Second World War (34). It is interesting to note that despite considerable improvements in evacuation of casualties, the recent discovery of antibiotics and the availability of blood little progress by way of results occurred. In their series only 81 arterial wounds were treated by suture repair of which $36 \%$ resulted in amputation. This compared favourably with the vast majority that were treated by ligation as Paré had advocated over four centuries earlier. The amputation rate in these cases was $50 \%$. It may appear at first sight that the nevertheless downbeat conclusions arrived at by the authors were somewhat pessimistic. The successful cases represented a highly selective and minor wounded group and therefore did not encourage a more widespread use of the technique.

When it is appreciated that in their series there were subgroups with lengthy delays from initial wounding to definitive help as long as 15 hours, their judgement can be seen to be based on sound premise and a realistic assessment of the times and conditions. Their paper made several important contributions despite the seemingly disappointing progress achieved during WWII itself; the appreciation that a much faster transit from the point of wounding to medical facility was essential if definitive vascular reconstruction was going to be feasible, the emphasis on the quality of debridement which was still required despite the advent of antibiotics and the recommendation that the ligature of the accompanying vein advocated by Makins (10), had no place in the management as there was no physiological evidence to support the practice. In the early months of the Korean War the practice of ligation of major arterial injuries continued. Studies carried out at the Walter Reed Army Hospital confirmed the very high morbidity due to resulting arterial insufficiency that occurred. This resulted in a change of policy in 1951 and using direct anastomosis, lateral repairs and graft replacement a 96\% success rate was achieved in the first series of 98 patients (35). This resulted in vascular reconstructive techniques being carried out in the M.A.S.H. units of Korea and in 130 cases $89 \%$ had limb-salvaging surgery performed. Carl Hughes eventually reported a $13 \%$ amputation rate following the repair of acutely injured blood vessels (36). This experience was to stand military vascular surgery in good stead for when the Vietnam War broke out the lessons learned in Korea were used to produce the Vietnam Vascular Registry under the guidance of Hughes and Norman Rich (Fig 6). In a review of 1000 arterial cases an $87 \%$ limb salvage rate was maintained among patients who represented a greater challenge to the surgeons because of

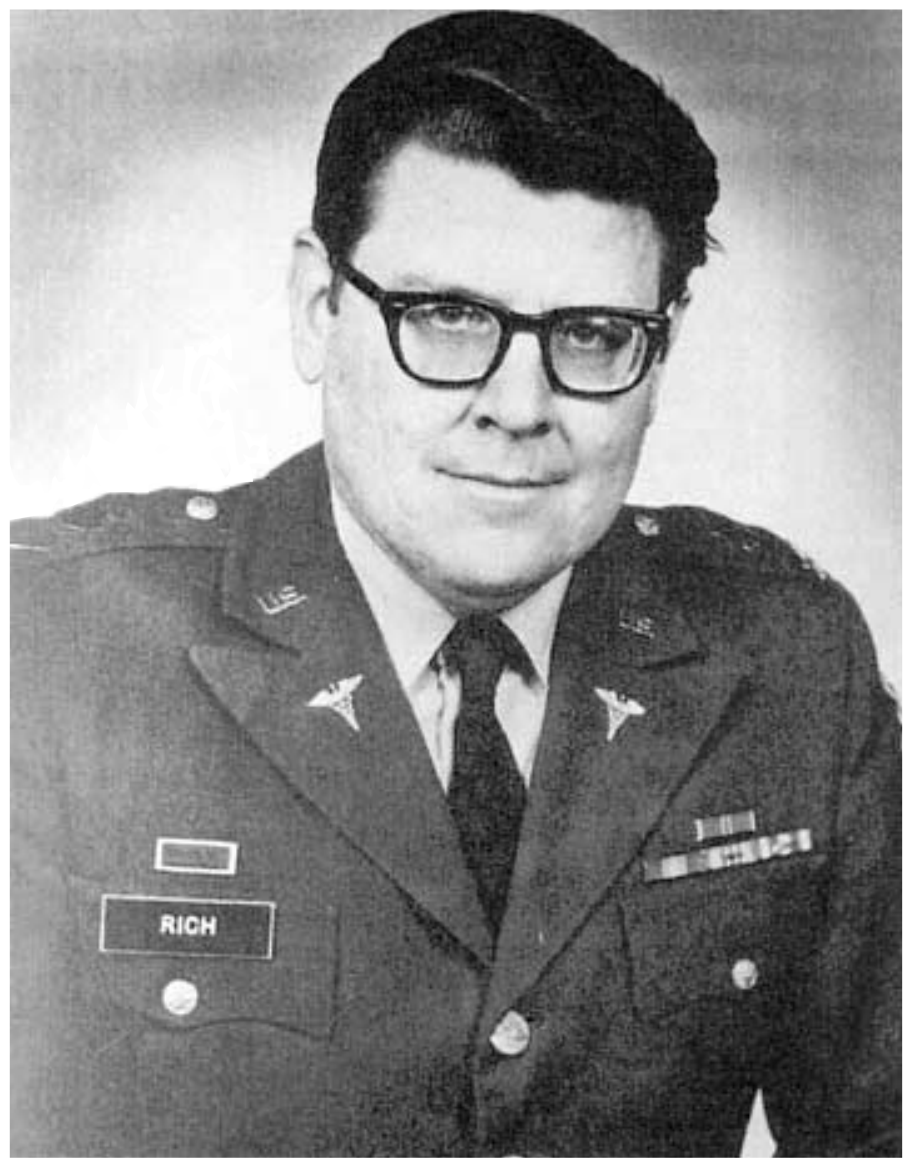

Fig 6. Norman Rich USA MC 
the improvements not only in vascular techniques but also in helicopter transportation. Every advance has its price and with the increasing demand for arterial repair came injudicious attempts to perform heroic operations in the name of limb salvage when amputation was clearly indicated. Nevertheless, the contribution made to military and civilian vascular surgery by the Vietnam experience has been immense and has included management of venous injuries, vessel trauma secondary to major fractures and specific problems associated with otherwise rarely seen arterial injuries (37).

\section{Conclusion}

Hippocrates once said "He who wishes to be a surgeon should go to war" and much has been learned on the battlefield. Since WWII major medical advances have taken place in parallel with advances in weaponry. The development of synthetic grafts by Arthur Voorhees (38), that are so taken for granted nowadays, are but one example as are the Forgarty balloon catheter (2) and the development of angioplasty by the interventional radiologists (39). The future holds further exciting developments with the advent of angioscopicallyassisted procedures, minimally invasive methods of vein graft harvest and endovascular stenting of aneurysms. However, none of these advancements would have been possible without the contribution made by the military surgeon - "Lest we forget".

\section{References}

1. Dos SAntos JC. Leriche Memorial Lecture. From Embolectomy to Endarterectomy or the fall of a myth. J Cardiovasc Surg 1976; 17: 117-28.

2. Fogarty TJ, Cranley JJ, Krause RJ, Strasser es, HAFNER CD. A method for extraction of arterial emboli and thrombi. Surg Gynecol Obstet 1963; 116: 241-244.

3. Dos Santos R, Lamas A, Pereirgi CJ. L'Arteriographie des membres de l'aorte et ses brances abdominales. Bull Soc Nat Chir 1929; 55: 587-601.

4. RoEntgen WK. Ueber eine neue art von Strahlen (trans) Nature 1896; 53: 274-276.

5. FrIEDMAN SG. A History of Vascular Surgery. New York: Future Publishing Company Inc, 1989.

6. Ellis H. Famous Operations Pennsylvania: Harwal Publishing Company, 1984.

7. Rutkow IM. Surgery. An Illustrated History. St Louis, Missouri: Mosby Year Book Inc, 1993.

8. A History of Medicine. CD ROM - First Multimedia Limited. FlagTower Publishers. 1996.

9. Soubbотітсн V. Military Experience of Traumatic Aneurysms. Lancet 1913; 2: 720-1.

10. MAKINS GH. Gunshot Injuries of Arteries Br Med J 1913; 2: 1569-77.

11. MAKINS GH. The Hunterian Oration on the Influence Exerted by the Military Experience of John Hunter on Himself and the Military Surgeon of to-day. Lancet 1917; 1: 249-54.

12. BernheIM B. Blood Vessel Surgery in the War. Surg Gynecol Obstet 1920; 30: 564-67.

13. JEGER E. Zur Technik der Blutgefaessennaht. Beitr Klin Wschr 1915; 97: 553-558.

14. ShUMACKeR HB. Ramuald Weglowski: Neglected pioneer in vascular surgery. J Vasc Surg 1987; 6: 95-7.

15. LAMBERT R. Extract of a Letter from Mr Lambert, Surgeon at Newcastle-upon-Tyne, to Dr Hunter; Giving an Account of a New Method of Treating an Aneurysm. Read June 15,
1761. Med Obs Inq 1762; 2: 360.

16. Lister J. On the Antiseptic Principle in the Practice of Surgery. Lancet 1867; 2: 353-6.

17. JASSINOWSKY A. Ein Beitrag zur Lehre von der Gefassnäht. Arch Klin Chir 1891; 42: 816-41.

18. CHILD CG. Eck's Fistula. Surg Gynecol Obstet 1953; 96: 375-6.

19. PAYR E. Zur Frage der Circulaeren Vereinigung von Blutgefaessen mit Resorbirbaren Prosthesen. Arch Klin Chir 1900; 62: 67-93.

20. PAYR E. Weitere Mittheilungen ueber Verwendung des Magnesiums bei der naht der Blutgefaessen. Arch Klin Chir 1901; 64: 726-740.

21. MurPhy JB. Resection of Arteries and Veins Injured in Continuity - End-to-end Suture - Experimental and Clinical Research. Med Rec 1897; 51: 73.

22. Bouglé J. La Suture Artérielle Etude Critique et Expérimental. Arch Med Exp D'Anat Path 1901; 13: 205224.

23. JABOUlay M, BRIAU E. Recherches Expérimental sur la Suture et la Greffe Artérielles. Lyon Med 1986; 81: 97-9.

24. KunLIN J. Le Traitement de l'Artérite Obliterante par la Greffe Veineuse Longue. Arch Mal Couer 1949; 42: 371-2.

25. Merrill JP, Murray JE, Harrison JH, Guild WR. Successful Homotransplantation of Human Kidney Between Identical Twins. JAMA 1956; 160: 277-82.

26. Malt RA, McKhann CF. Replantation of Severed Arms. JAMA 1964; 189: 716-22.

27. BARNARD CN. A Human Cardiac Transplant: An Interim Report of a Successful Operation Performed at Groote Schuur Hospital, Cape Town. S Afr Med J 1967; 41: 12714.

28. CARrel A. Experimental Operations on the Orifices of the Heart. Ann Surg 1914; 60: 1-6.

29. CARrel A. Experimental Operations on the Sigmoid Valves of the Pulmonary Artery. J Exp Med 1914; 20: 9-18.

30. CARrel A. On the Experimental Surgery of the Thoracic Aorta and the Heart. Ann Surg 1910; 52: 83-95.

31. Carrel A, Burrows MT. Human Sarcoma Cultivated Outside of the Body. JAMA 1910; 55: 1732.

32. Carrel A, Dakin H, Daufresne J. Traitement abortif de l'Infection des Plaies. Bull Acad Med Paris 1915; 74: 361368.

33. Carrel A, Lindbergh CA. The Culture of Organs. New York: PB Hoeber, Inc., 1938.

34. Debakey ME, Simeone FA. Battle Injuries of the Arteries in World War II. An Analysis of 2,471 Cases. Ann Surg 1946; 123: $534-79$.

35. Seeley SF, Hughes CW, Jahnke EJ Jr. Direct Anastomosis Versus Ligation and Excision in Traumatic Arteriovenous Fistulas and Aneurysms. Surg Forum, Clin Cong Am Coll Surg. Philadelphia: WB Saunders Co, 1953.

36. Hughes CW. Vascular Surgery in the Armed Forces. Milit Med 1959; 124: 30-46.

37. Rich NM, Baugh JH, Hughes CW. Acute Arterial Injuries in Vietnam: 1,000 Cases. J Trauma 1970; 10: 359-69.

38. Blakemore AH, VoorheEs AB Jr. The Use of Tubes Constructed from Vinyon " $N$ " Cloth in Bridging Arterial Defects - Experimental and Clinical. Ann Surg 1954; 140: 324-34.

39. DotTer CT, Judkins MP. Transluminal Treatment of Arteriosclerotic Obstruction. Description of a New Technic and a Preliminary Report of its Application. Circulation 1964; 30: 654-70. 